\title{
RISK AND THE MANAGEMENT OF A HEALTHCARE UNIT - A LITERATURE REVIEW
}

\author{
RYZYKO W ZARZĄDZANIU JEDNOSTKĄ OCHRONY ZDROWIA \\ - PRZEGLĄD LITERATURY
}

https://doi.org/10.34739/zn.2021.55.04

\author{
Andrzej Szewczuk ${ }^{1}$, Emilia Magdalena Kugowska², Jari Kruth ${ }^{3}$ \\ ${ }^{1}$ Poland, Independent Public Healthcare Center in Siemiatycze, \\ ndrzej_szewczuk@op.pl, ORCID: 0000-0002-1393-035X \\ 2 Poland, Mazovia Regional Hospital in Siedlce, \\ emilia.lugowska1990@gmail.com, ORCID: 0000-0002-1935-3362 \\ 3 Switzerland, Piomic Medical AG \\ kruth@piomic.com, ORCID: 0000-0002-4222-5457
}

JEL Classification Codes: M10

\begin{abstract}
Due to its specific nature, the provision of medical services is associated with considerable risk; and it is extremely important to diagnose and manage this same risk. Healthcare entities should be covered by appropriate instruments that reduce risk and support quality. In addition to legal regulations that must be met by entities providing such services, there are systemic solutions that are being implemented by more and more healthcare entities. The article analyses the risk that occurs in the management of a health care unit. In the first part of the article, the literature on the topic is reviewed, whereas what follows thereafter analyses risks in the management of a healthcare unit, including risk factors and risk allocation. The conclusion points to the risks which play the greatest role in the management of medical service providers; and enumerates some of the most important issues of risk management in medical entities.
\end{abstract}

Key words: risk, risk management, types of risk, health care units

Streszczenie: Świadczenie usług medycznych ze względu na swoją specyfikę wiąże się z ogromnym ryzykiem. Niezmiernie ważne jest zdiagnozowanie i zarządzanie ryzykiem. Podmioty ochrony zdrowia powinny zostać objęte odpowiednimi narzędziami, które ograniczają ryzyko i podnoszą jakość. Poza regulacjami prawnymi, które muszą spełnić podmioty świadczące usługi medyczne, pojawiają się systemowe rozwiązania, które wdraża coraz więcej podmiotów leczniczych. Artykuł analizuje ryzyko, które występuje w zarządzaniu jednostką służby zdrowia. Pierwsza cześć artykułu to przegląd literatury w podjętym temacie, w kolejnej części artykułu analizowane jest ryzyko w zarządzaniu jednostką służby zdrowia, w tym czynniki ryzyka i podział ryzyka. W końcowej części artykułu zawarte są wnioski autorów dotyczące ryzyka w podmiotach medycznych. Zwrócono uwagę na ryzyka, które odgrywają największą rolę w zarządzaniu podmiotami świadczącymi usługi medyczne.

Słowa kluczowe: ryzyko, zarządzanie ryzykiem, rodzaje ryzyka, jednostki ochrony zdrowia

\section{Introduction}

In economic studies, the notion of risk can be found in Adam Smith and David Ricardo; however, it was treated in these instances as a typical element of a company's environment. Attempts to present economic theories pertaining to risk appeared in the doctoral dissertation of Allan $\mathrm{H}$. Wilett in 1901. It is commonly believed that a comprehensive risk assessment was presented in 1921 by Frank $\mathrm{H}$.
Knight (Adamska, 2014, pp. 22-23). He proposed a division into two categories: measurable uncertainty and unmeasurable uncertainty. However, his theory of large numbers was criticized by the well-known economist J.M. Keynes. In 1926, the outstanding mathematician and physicist John von Neumann presented his theory of strategic games in Göttingen (Kaczmarek, 2010, pp. 45-46). Another important publication was an article by Harry Markowitz, "Portfolio Selection", where he presented the operational rules governing the stock 
exchange and investors who make rational decisions and not spontaneous choices. This theory was awarded the Nobel Prize in 1990 (Jabłoński, 2009, p. 25). In recent years, more theories have built on the earlier body of work, and today that new risk measurement tools have been proposed and assumptions have been identified.

Three standpoints revealing attitudes to risk may be distinguished:

- Risk aversion means that actions with uncertain consequences are only taken in the event of expected profit,

- Risk indifference or neutrality indicates that the magnitude of the risk does not influence all decisions,

- The tendency to risk means that decisions and actions are taken which are burdened with the highest degree of risk, even those burdened with additional costs (Jajuga, 2019, pp. 19-20).

The divisions have also led to the further development of theoretical tools, risk control instruments and appropriate risk management regulations.

From the beginning of the 1990s, work was undertaken to standardize risk assessment systems and to reduce areas of uncertainty. Subsequent numerous financial and economic scandals drew attention to new and previously unknown threats. The need for more complete auditing, oversight and risk reporting was recognized. Integrated risk management system standards were developed, the most well-known being:

- FERMA - Risk management standard developed by the Federation of European Risk Management Associations,

- COSO - Enterprise Risk Management Integrated Framework,

- ISO 31000: 2009 - a standard from the ISO family whose task is to organize the terminology and define the elements of the risk management process (Wieczorek-Kosmala, pp. 65-67).

In the literature, the term risk is often interchangeable for uncertainty. Some authors, following Frank Knight, distinguish between uncertainty and risk. According to Knight, uncertainty occurs when probability methods cannot be used in the analysis of an uncertain situation (Wieczorek-Kosmala, 2017, p. 67).

The risk management process can be into three stages.

In the first step, the importance of individual parameters should be defined, which are then monitored. Their influence on the goals set by the organization should be determined.
The second step is to assess the risk by:

- risk identification, i.e. identification of threats that may affect the company's operations,

- risk analysis consisting in measuring the frequency or probability of unfavourable phenomena and assessing the strength of their consequences,

- risk evaluation consisting in supplementing the analysis with an assessment of the impact of the phenomena on the achievement of the intended goals.

In the third step, appropriate risk management methods should be selected; most often these are risk financing methods and physical risk control. The method of physical risk control involves:

- avoiding the risk of not taking actions that will not guarantee success,

- risk reduction consisting in the use of techniques and methods to reduce the frequency of unfavourable phenomena and their effects (prevention and repression method).

However, risk financing methods include:

- retention - consisting in stopping the risk by financing its effects,

- transfer - the transfer of risk effects another entity (Wieczorek-Kosmala, 2017 p. 67).

\section{Risk analysis in a healthcare entity}

In the breakdown of risk depending on the location in the company's environment presented by Agata Adamska (2014), we note significant risks also for healthcare entities.

- Organizational risk is related to the proper conduct of operational activities, implemented technologies and processes, dependence on employees. Whereas in the medical entity the issue of medical personnel, particular where there are shortages, is of particular importance now; this issue was especially brought to the fore by the Covid 19 pandemic, although the problem of lack of personnel for many years medical care exists, which has many consequences, including rising costs of hospitals due to high salaries of doctors.

- Legal risk refers to losses resulting from conducting business in a manner inconsistent with the law, related to legal regulations and the risk of activities inconsistent with applicable law, includes compliance with legal regulations specified in regulations, including civil and administrative law. Legal regulations define the entire activity of medical entities, including regulations of the Polish Ministry of Health, the Polish National Health Fund (NFZ). 
- Financial risk is expressed in the method of managing settlements and resulting from the financing structure of the medical entity's operations. In the case of contracts with the National Health Fund, 'l' remain the most important payer.

- Economic risk is examined in terms of achieving the intended economic goals, market share, etc.

- Organizational risk occurs in the organization, and relates to the adopted ways of organizing activities, technologies used, technological solutions, internal control, qualifications and selection of employees.

- Epidemiological and medical risk relate to the occurrence of diseases and epidemics, which especially shows how large a pandemic can take hold, such as the COVID-19 pandemic,

- Pharmaceutical risk relates to the production of drugs, research into new products and mitigation of side effects and complications of currently used preparations.

- Chemical risk concerns living creatures and the natural environment, assesses the degree of exposure of human life and health to harmful and toxic substances.

- Psychological risk, presented as situations causing stress, fear of the unknown, is also very significant in the current COVID 19 situation. We are seeing this risk especially in hospitals with overworked staff coping with COVID-19; but this risk also applies to patients. Needless to say, this risk has many consequences.

- Sociological risk, which studies the behaviour of social groups and individual individuals - especially their behaviour in the face of threats and natural disasters.

- Cultural and civilization risk is related to the diversity of cultures, different perceptions of civilization development.

- Ethical, philosophical and religious risk concerns the development of the material and spiritual world, determines the relationship between man and society, it is an important risk in medical personnel.

Adamska even draws attention to media risk, where with the development of the Internet and the strengthening of the mass media, there is a danger of influencing and manipulating public opinion.

A classification of risk was also made by Tadeusz T. Kaczmarek, wherein distinguishes the following areas of risk: politics, law, economy, new technologies and technology, ecology, medicine, pharmacy, sociology, psychology, ethics, philosophy, culture (Kaczmarek, 2010, pp. 73-74).
Here we may emphasize the risks that concern medical entities, which are:

- systematic risk, which occurs in the environment of the organization: forces of nature, economic conditions - the entity cannot avoid it or diversify it.

- specific risk, which is partly controlled and diversified: part of it is primary risk, related to activities in a given market area, and secondary risk - avoidable and diversified - which makes recourse to appropriate financial instruments.

One of the most important elements of specific risk is financial risk, which has a decisive influence on the results of operations. It arises when the entity finances its activities from external sources, and then has a problem with the timely payment of liabilities. Business entities are also exposed to market risk due to the fact that the market for goods and services is volatile, a change in the value of assets may generate wither profits or losses. Krzysztof Jajuga provides a breakdown of the main components of market risk: exchange rate risk, and interest rate risk (Jajuga, 2019, pp. 26-27).

Credit risk exists in situations pertaining to the taking of taking loans and to difficulties arising from the timely repayment of liabilities. From the point of view of medical practice, operational risk is related to ongoing operations, making wrong decisions, insufficient control, and human error. Operational risk is extremely close to day-to-day aspects of medical entities providing medical care. Decisions are made that determine human health and life, there are human errors that have the most important consequences in human health and life, but also legal and financial consequences for medical personnel and hospitals themselves or other medical entities. Nowadays, the medical and management staff is definitely aware of this risk, as this risk can entail huge financial losses.

The task of each entity is to analyse what types of risk it is exposed to, and which of these are of key importance in terms of further development or hindrance. None of the factors should be taken lightly.

Measurement is a very important step in risk management. There are many mathematical methods, and new tools are emerging all the time, taking into account different variables. They mainly concern ordinary risk, i.e. risk encountered in organizations operating on a given market. Some measures allow us to objectively determine some dependencies, others depending on a specific organization and its attitude to risk. Krzysztof Jajuga has proposed the following risk measures. 
Taking into account the nature of the risk, the following can be distinguished:

- Measures based on the statistical distribution of a random variable - the effect of risk on possible outcomes is assessed.

- Measures resulting from the dependence of the risk variable function on the factors causing them - the analysis covers the risk cause and the assessment of sensitivity measures.

- Risk measures presented as risk classes - risk is perceived in imprecise categories, e.g. low, medium, high. Only the risk effect is analysed. Some measures test similar relationships others are mutually exclusive (Jajuga, 2019, pp. 51-52).

Many variables can be analysed. These can be random variables: discrete and continuous. Each variable has a characteristic distribution of features. We can also evaluate the tested level of risk in one dimension - assessing each risk separately, or in a multidimensional manner as a whole.

For entities operating in the healthcare sector, Opolski and Waśniewski recognized three interacting elements as the most important:

- obtaining the appropriate accreditation,

- Financial Liquidity,

- contracts with the National Health Fund and institutional payers (Opolski, Waśniewski, 2012, pp. 34-35).

Every strategy and plan in this industry should be based on the reliable identification of threats. Specify what types of events are, how often they occur, and what are their causes and effects. Risk estimation depends on two variables: the probability of the occurrence of damage and its extent. Risk management consists in minimizing the probability of the occurrence of threats and possible damages and their consequences. Healthcare entities are exposed to common risks, such as:

- Financial risk is a set of all partial external types of risk, directly affecting the financial position of the entity.

- Operational risk includes all types of risk that have a direct impact on the ability to conduct planned activities specified in the strategy or the operating activity itself of each entity. The severity of this risk is assessed on the basis of the damage and its extent to property, people, control systems, data processing or the environment. The period of these disruptions and the time needed to restore the continuity of the organization's activities are also important. Disruptions in the availability of appropriately qualified personnel are somewhat different. Sometimes this group also includes technological risk and specific factors related to key projects: e.g. the procedure for obtaining the necessary permits, the lack of systematic execution of subsequent stages of the plan, unforeseen costs and workload, unavailability of certain resources and technologies.

- Legal risk covers independent areas of threats: legal status and changes to these regulations, claims of other entities, and the risk of failure to comply with previous agreements and legal obligations.

- Strategic risk is a type of threat that may disrupt the implementation of long-term and strategic plans. The factors are mainly the phenomena causing particular dependence on external entities. These can be: a small number of customers and suppliers, a small variety of products or services, complex technology, lack of access to new resources or too strong competition.

- Systemic risk is a type of activity whose effects occurring inside the organization spread to the external environment.

The presented classification of risk types takes into account the basic assumptions of insurance mathematics. The precise definition of the group of events helps us to better estimate the risk. The organization can achieve the planned effects if the processes run smoothly in individual areas. The main causes of risk include:

- mistakes made by employees and deliberate violations of established rules,

- damage to material resources and system failures,

- mistakes made in the management of the organization.

Risk often takes the form of minor but frequent events or occasional catastrophes. Minor negative issues actually always occur, some of which are predictable. Their impact is small, but the effects are cumulative and ultimately cause large losses.

Another risk that is very specific to the healthcare sector is clinical risk. The first publications on this subject appeared in California in 1977. It was a research programme of the HMPS (Harvard Medical Practice Study), which analysed patients' charts using a retrospective method. The histories of diseases and related complications as well as health detriment due to medical malpractice and negligence resulting from an inappropriate operating system of the organization were shown and analysed. Such actions are referred to as clinical damage (Opolski, Waśniewski, 2012, p. 48). Krzysztof Opolski presents clinical risk as a type of loss and uncertainty related to the malfunctioning of the organization and not individual medical cases. Therefore, clinical risk in health services should be treated as an element of operational risk. It is known that all errors and clinical damages have their unpleasant consequences in the form of a loss of reputation, financial damages and legal 
consequences. The subject of clinical harm is still of interest to researchers. Many studies and analyses have been carried out around the world taking into account various evaluation criteria. The HMPS method was originally intended to be helpful in estimating costs and compensation for patients. However, it was quickly noted that it allows for the comparison of certain repeated errors, omissions and negligence committed by the organization and staff, regardless of the specificity of the facility and the clinical condition of the patients. In different countries, analyses showed similar groups of factors leading to clinical harm, and the groups of patients most at risk. In Belgium, it was noted that failure to assist and medical malpractice were the most common factors causing harm. In Australia, language barriers were strongly indicated in terms of negative occurrences. Other important reasons include improper flow of information among staff, negligence in documentation, lack of procedures for dealing with disruptions and emergency situations. In Poland, the reality is rather similar. Clinical risk management is performed through internal controls and contingency plans. It is very important to keep patients safe. The redress awarded by the courts is high. It is estimated that medical malpractice occurs in around $10 \%$ of hospitalizations in the European Union (Opolski, Waśniewski, 2012, p. 53). However, it is impossible to completely avoid the damage and its unpleasant consequences. The two most common scenarios are related to each other

- clinical damage causes further damage, e.g. hospital infections,

- the damage gives rise to the patient's claims the dispute resolved by the court generates costs.

Clinical risk management is designed to minimize the harm that may result from both scenarios. It is known that man learns from mistakes - unfortunately most from his own. It is similar in the organization - often a facility taught by experience in the future reacts more vigilantly to some disturbing phenomena and signals. The consequences can be twofold: increased vigilance, setting up new procedures in certain cases.

Risk analysis allows for the identification of certain warning situations that, without an appropriate preventive response, may cause a domino effect, triggering a whole range of unfavourable events:

- Re-admission of the patient to the hospital unscheduled after premature termination of treatment.

- Unplanned transfer of patients between departments or hospitals.

- Unplanned transfer to the intensive care unit.

- Emergency returns to the operating theatre.
- Documented and justified patient dissatisfaction.

- Incorrect discharge of the patient home.

A typical scenario of operation should include a thorough analysis of the procedures being applied. Then the compliance of their application in practice by the personnel of the assessed cell. It is necessary to analyse the causes of the event. It is worth emphasizing that clinical damage has a special type of harmfulness. They often cause permanent damage to health or even loss of life. Most are due to human factors. Often such events occur through evident neglect or lack of knowledge, but sometimes serious damage may be caused by an apparently minor failure to fulfil obligations, e.g. not asking about allergies. Krzysztof Opolski and Krzysztof Waśniewski present a list of the most common threats in managing health services.

- No possibility of employing doctors with specializations.

- Inability to enforce non-competition clauses.

- Inefficiency of operating systems containing medical and financial information and reluctance to implement new systems.

- Disclosure of patient data.

- Lack of stability in the implementation of previously concluded contracts with: doctors, hospitals, service providers.

- Possible violations of anti-corruption laws by doctors or service providers.

- Discrepancies in the data of persons entitled to reimbursed benefits held by the payer and the service provider:

- Inadequate forecasting of costs and real feasibility of services.

- Refunds disproportionate to the cost and workload or late payment of the reimbursement.

- Potential for fraud and incorrect billing (Opolski, Waśniewski, 2012, pp. 58-59).

In Poland, the legal act in the field of risk management in medical activities determines third party liability for damages caused by the Regulation of the Minister of Finance of April 29, 2019 on compulsory third-party liability insurance for the entity performing medical activities (Dz.U. 2019 poz. 866).

\section{Conclusions}

In Poland, in order to avoid the above risks, various solutions have been introduced in healthcare entities: wristbands with encoded patient data were introduced for faster identification, the E-WUŚ system was implemented to confirm patients' entitlements to reimbursement by verifying the payment of health insurance contributions, a system was created for issuing electronic 
exemptions, and an electronic patient account was set up. E-services were quickly implemented: teleconsultations, online patient registration (Kaczmarska-Krawczak, 2013), e-prescriptions, etc. These IT solutions have gained particular importance as a result of the COVID-19 pandemic. For the majority of Polish healthcare entities, the most important condition for business continuity is a contract with the National Health Fund or another institutional payer. It is worth noting that there are some warning events that can lead to the loss of a contract. They can be:

- Control results on the part of the payer, unfavourable for the unit.

- Unexpected change in service quality requirements.

- Unexpected staff changes in a medical facility.

- Increase in operating costs.

- Increased clinical harm and victim claims.

Due to its specific nature, the provision of medical services should be covered by appropriate tools supporting quality and the reduction of risk. In addition to legal regulations that must be met by entities providing such services, there are systemic solutions that are implemented by more and more

\section{References}

Adamska, A. (2014). A. Adamska 'Ryzyko jako przedmiot nauk ekonomicznych' ['Risk as a subject of economic sciences'] in, Ryzyko lokalizacji przedsiębiorstw w Polsce [The risk of localizing enterprises in Poland] ed. K. Kuciński. Warszawa: CeDeWu.

Alam, A.Y., (2016). Steps in the Process of Risk Management in Healthcare, Journal of Epidemiology and Preventive Medicine A 2(2): 118. DOI: 10.19104/jepm.2016.118.

Dückers, M., Faber, M., Cruijsberg, J., Grol, R., Schoonhoven, L., Wensing, M., (2009). Safety and risk management in hospitals, London, https://www.health.org.uk/sites/default/files/Safe tyAndRiskManagementlnHospitals.pdf.

Głód, G., Głód, W. (2017). Grzegorz Głód, Wojciech Głód, W kierunku integracji systemów zarządzania jakością i ryzykiem w publicznych jednostkach ochrony zdrowia [Towards the integration of quality and risk management systems in public health care units'], Studia Ekonomiczne. Zeszyty Naukowe, Uniwersytetu Ekonomicznego w Katowicach 316, pp. 82-93].

Jabłoński, D. (2009). Ryzyko przedsiębiorstwa w pracach laureatów Nagrody Nobla ['Enterprise risk in the works of Nobel Prize winners'], in ed. A. Fierla, Ryzyko w działalności przedsiębiorstw wybrane aspekty [Risk in the operation of enterprises - selected aspects]. Warszawa: SGH Warszawa. healthcare entities. In the field of quality management, the possibility of implementing quality management systems according to ISO and accreditation standards, the correctness of which is verified by the Quality Monitoring Center (CMJ), should be indicated (Głód, Głód, 2017, pp. 82-93). The implementation of both systems contributes to the creation of greater benefits than when using the selected system (Lisiecka-Biełanowska, Lisiecka, 2008, pp. 224-225). In addition, in the case of public healthcare entities, the scope of the proposed comparative analysis should be extended to the risk management context, as these entities are required to apply management control standards that also cover the area of risk management.

Faced with the requirements established by the supervisory and controlling bodies on the one hand, and patients on the other, institutions may decide to implement their own quality management systems. The most frequently used quality management systems, which should guarantee the high quality of medical services, are the accreditation programme and ISO standards (Szetela, 2011).

Jajuga, K. (2019). Zarządzanie ryzykiem [Managing Risk]. Warszawa: Wydawnictwo PWN 2nd ed.

Kaczmarek, T. (2010). Zarządzanie ryzykiem ujęcie interdyscyplinarne [Risk management interdisciplinary approach]. Warszawa: Difin.

Kaczmarska-Krawczak, J., (2013). Zarządzanie informatyzacją w procesach restrukturyzacji jednostek ochrony zdrowia [IT Management in the restructuring processes of healthcare units] Zarządzanie i Finanse 4(11), 246.

Komunikat Ministra Finansów $\mathrm{Nr} 23$ z dnia 16 grudnia 2009 r. w sprawie standardów kontroli zarządczej dla sektora finansów publicznych.

Lisiecka-Biełanowicz, M., Lisiecka, K. (2008). Certyfikować czy akredytować systemy zarządzania jakością usług zdrowotnych? [To certify or accredit health services quality management systems] In, R. Lewandowski (ed.), Współczesne wyzwania strukturalne $i$ menedżerskie $w$ ochronie zdrowia [Contemporary structural and managerial challenges in health care]. Olsztyn: Katedra Organizacji i Zarządzania, Wydział Nauk Ekonomicznych, Uniwersytet Warmińsko- Mazurski w Olsztynie, pp. 224-225.

Opolski, K., Dykowska, G., Możdżonek, M. (2003). Zarządzanie przez jakość w usługach zdrowotnych. Teoria i praktyka, [Quality and risk management in health services. Theory and practice]. Warszawa: CeDeWu. 
Opolski, K., Waśniewski, K. (2012). Zarządzanie jakością i ryzykiem w usługach zdrowotnych [Quality and risk management in health services]. Warszawa: CeDeWu.

Marczak, M. (2008). Risk management in health care system - methodology and chosen examples, Technical University of Lodz, file://C:/Users/

Admin/AppData/Local/Temp/Riskmanagementin healthcaresystem.pdf.

Sasak, J. (2020). Zarządzanie ryzykiem w placówkach ochrony zdrowia. Warszawa, Wolters Kluwer.
Szetela, A. (2012). Zewnętrzne metody oceny jakości w ochronie zdrowia - akredytacja i system zarządzania jakością według normy [External methods of quality assessment in health care - accreditation and quality management system according to the standard], Problemy Zarządzania 37, pp. 211-228.

Wieczorek-Kosmala, M. (2017). Kapitał ryzyka w przedsiębiorstwie [Risk capital in business], Warszawa: CeDeWu.

https://www.scielo.br/j/ean/a/cSfZ9h59ynwyQmgjk QwQL8t/?lang=en\&format=pdf. 